\title{
The Relationship Between Exclusive Breastfeeding with Nutritional Status at Children Aged 7-18 Months in Puskesmas Pupuan I
}

\author{
I G P W E Nugraha ${ }^{1}$, P Sutisna ${ }^{1}$, P N Cahyawati ${ }^{1 *}$ \\ ${ }^{1}$ Faculty of Medicine and Health Sciences, Warmadewa University, Bali, Indonesia \\ *putunitacahyawati@gmail.com
}

\begin{abstract}
Malnutrition in children is very difficult to overcome and some cases of malnutrition have caused death in children. Malnutrition prevalence in children under five in Bali is still high (13\%). Nutrition condition in children is affected by several factors, one of which is exclusive breastfeeding. The purpose of this study was to find out the relationship between exclusive breastfeeding and nutritional status of children aged 7-18 months in Puskesmas Pupuan I, Bali. This study used cross-sectional analytic design, and studied were status and nutritional status, with a total sample of 140 mothers, selected by simple random sampling technique. Data of exclusive breastfeeding were acquired directly using a questionnaire and the nutrition status was measured using secondary data from Kartu Menuju Sehat (KMS) which then was converted into anthropometry table. Data were analyzed using bivariate analysis with the chi-square test $(\alpha=0,05)$ and multivariate analysis with logistic regression test, with confounding variables included in the analysis. The study results showed that $50 \%$ of 718 month-old children received exclusive breastfeeding, $17.9 \%$ was malnutrition, and $82.1 \%$ of children had good nutrition. The multivariate analysis showed, exclusive breastfeeding had the strongest influence on the nutritional status of children aged 7-18 months ( $\mathrm{p}=$ 0.030; OR $=3,005)$, compared with calories intake $(\mathrm{p}=0,035$; $\mathrm{OR}=2,967)$ and protein intake ( $\mathrm{p}=0,035$; $\mathrm{OR}=2,896$ ). It is recommended that the mother should be encouraged to give exclusive breastfeeding, to prevent malnutrition in children.
\end{abstract}

Keywords: Relationship, Exclusive Breastfeeding, Children.

\section{Introduction}

Breast milk contains ingredients that are needed by babies [1]. The nutrition contained in breast milk includes complete nutrients, immune factors, and growth, hormones, anti-allergic and anti-inflammation. Baby growth getting breast milk is mostly normal, especially babies who get breast milk exclusive [2]. Exclusive breastfeeding coverage at Indonesia is relatively low. Riset Kesehatan Dasar (Riskesdas) data in 2013 said that the coverage of national exclusive breastfeeding only reached 30.2\%. Data from Badan Kependudukan dan Keluarga Berencana Nasional (BKKBN) in 2012 mentions the average long time exclusive breastfeeding in Bali Province is until the baby 1 month old. This condition shows that exclusive breastfeeding is still low in Bali Province [3,4]. The low level of exclusive breastfeeding can cause a decrease in nutritional status in children because in breast milk there is an important component for the growth of children [5]. Decreasing nutritional status is one of the factors that cause death in children. Children who do not get exclusive breastfeeding when they are under the age of 6 months tend to be less likely to grow optimal, because of the 
nutritional intake that is obtained insufficient, so it affects child nutritional status [2.6]. Based on these problems, researchers are interested to assess the relationship between exclusive breastfeeding with nutritional status in children aged 7-18 months at Puskesmas Pupuan I Work Area.

\section{Method}

\subsection{Place and time of research}

This research was conducted in the work area Puskesmas Pupuan I. Based on the results of random sampling the location of the study, namely Pujungan Village, Pajahan Village, Batungsel and Desa Pupuan. This research carried out in September-December 2017.

\subsection{Population and samples}

This study uses analytical methods with a cross-sectional approach. The population in this study was all toddlers aged 7-18 months in the work area of Puskesmas Pupuan I in December 2017. The total sample was 140 people. Technique the sampling used is simple random sampling.

\subsection{Reseach variable}

This study uses three variables, namely independent variable (exclusive breastfeeding), dependent variable (nutritional status of children aged 7-18) month) and confounding variable (calorie intake, protein intake, the incidence of illness).

\subsection{Data collection}

The data used in this study are primary data obtained directly through the interview process to respondents in the form of the proportion of mothers giving exclusive breastfeeding, consumption of MP-ASI, and the incidence of illness. the secondary data obtained from Kartu Menuju Sehat (KMS) children aged 7-18 month for know the nutritional status.

\subsection{Data analysis}

There are three analyzes used in this study, namely univariate, bivariate analysis and multivariate. The univariate analysis aims to describe the frequency distribution of maternal characteristics as respondents and characteristics of children aged 7-18 months. Bivariate analysis was used to see the relationship between each independent variable and confounding variables with dependent variables. Multivariate analysis was carried out by a logistic regression test. The purpose of multivariate analysis is to determine the significant relationship and the influence of independent variables with variables depends after confounding variables are included in the analysis.

\section{Results And Discussion}

The characteristics of mothers who acted as respondents in this study are analyzed using univariate analysis. 
Table 1. Characteristics of Mothers as A Respondents $(n=140)$

\begin{tabular}{lcc}
\hline \multicolumn{1}{c}{ Variable } & F & $\%$ \\
\hline Age & 23 & 16.4 \\
16-20 y.o & 54 & 38.6 \\
21-25 y.o & 36 & 25.7 \\
26-30 y.o & 16 & 11.4 \\
31-35 y.o & 11 & 7.9 \\
36-40 y.o & & \\
Last education & 19 & 13.6 \\
Elementary school & 44 & 31.4 \\
Junior high school & 50 & 35.7 \\
High school & 27 & 19.3 \\
College & & \\
Work & 36 & 25.7 \\
Housewife & 63 & 45.0 \\
Private employees & 24 & 17.1 \\
Government employees & 17 & 12.1 \\
Entrepreneur & & \\
\hline
\end{tabular}

Table 1 shows the age of the respondent most are in the age group 21-25 year, namely 54 people (38.6\%) and the lowest in the age group of 36-40 years 11 people (7.9\%). Majority last education of the respondents are senior high school 50 people (35.7\%) and number respondents with elementary school level is the lowest as many as 19 people (13.6\%). Most respondents are 63 people (45\%) work as private employees and at least 17 people (12.1\%) work as an entrepreneur.

Table 2. Characteristics of 7-18 Month Ages Based on Respondents Information ( $\mathrm{n}=140)$

\begin{tabular}{lcc}
\hline \multicolumn{1}{c}{ Variable } & F & $\%$ \\
\hline Age & & \\
7-10 month & 39 & 27.9 \\
11-14 month & 44 & 31.4 \\
15-18 month & 57 & 40.7 \\
Sex & & \\
$\quad$ Male & 72 & 51.4 \\
$\quad$ Female & 68 & 48.6 \\
Breastfeeding & & \\
$\quad$ Exclusive & 70 & 50 \\
$\quad$ Non exclusive & 70 & 50 \\
Calori intake & & \\
$\quad$ Less & 51 & 36.4 \\
$\quad$ Enough & 89 & 63.6 \\
Protein intake & & \\
$\quad$ Less & & \\
Enough & 50 & 35.7 \\
The inciden of illness & 90 & 64.3 \\
$\quad$ Yes & & \\
$\quad$ No & 57 & 40.7 \\
\end{tabular}




\begin{tabular}{lcc} 
Nutritional status & & \\
Poor & 25 & 17.9 \\
Good & 115 & 82.1 \\
\hline
\end{tabular}

The results of bivariate analysis showed exclusive breastfeeding $(p=0.047$; OR $=2.50)$, caloric intake $(\mathrm{p}=0.002 ; \mathrm{OR}=4.06)$, protein intake $(\mathrm{p}=0.001 ; \mathrm{OR}=4.23)$ and incidence of illness $(\mathrm{p}=0.030 ; \mathrm{OR}=2.60)$ has a meaningful relationship with nutritional status of children aged 7-18 months (Table 3 ).

Table 3. Bivariate Analysis of Exclusive Breastfeeding, Calorie Intake, Protein Intake and Incidence of illness with Nutritional Status of Children aged 7-18 Months

\begin{tabular}{|c|c|c|c|c|}
\hline \multirow{2}{*}{ Variable } & \multicolumn{2}{|c|}{ Nutritional Status } & \multirow[t]{2}{*}{$p$} & \multirow[t]{2}{*}{ OR } \\
\hline & Poor & Good & & \\
\hline \multicolumn{5}{|l|}{ Breastfeeding } \\
\hline Exclusive & $17(24.3 \%)$ & $53(75.7 \%)$ & 0.047 & 2.50 \\
\hline Non exclusive & $8(11.45)$ & $62(88.6 \%)$ & & \\
\hline \multicolumn{5}{|l|}{ Calori intake } \\
\hline Less & $16(31.4 \%)$ & $35(68.6 \%)$ & 0.002 & 4.06 \\
\hline Enough & $9(10.15)$ & $80(89.9)$ & & \\
\hline \multicolumn{5}{|l|}{ Protein intake } \\
\hline Less & $16(32 \%)$ & $34(68 \%)$ & 0.001 & 4.23 \\
\hline Enough & $9(10 \%)$ & $81(90 \%)$ & & \\
\hline $\begin{array}{l}\text { The inciden o } \\
\text { illness }\end{array}$ & $15(26.3 \%)$ & $42(73.7 \%)$ & 0.030 & 2.60 \\
\hline Yes & $10(12 \%)$ & $73(88 \%)$ & & \\
\hline No & & & & \\
\hline
\end{tabular}

Multivariate analysis shows three variables that have values $\mathrm{p}<0.05$ which is breastfeeding, calorie intake and protein intake. While the value of $\mathrm{p}$ on the incidence of illness $>0.05$, which means the incidence of illness is not significantly related to nutritional status compared to variables others. From the results of multivariate analysis, it can conclude that there are three variables effect on nutritional status, i.e. breastfeeding, calorie intake and intake protein (Table 4).

Table 4. Relationship between Exclusive Breastfeeding, Calorie Intake, Protein Intake and incidence of illness with Nutritional Status in Children

\begin{tabular}{lcccc}
\hline \multicolumn{1}{c}{ Variable } & \multirow{2}{*}{ OR } & \multirow{2}{*}{ OR } & \multicolumn{2}{c}{ 95\% C.I. for EXP(B) } \\
\cline { 4 - 5 } & & & Lower & Upper \\
\hline Breastfeeding & $0.030^{*}$ & 3.005 & 1.113 & 8.116 \\
Calori intake & $0.035^{*}$ & 2.967 & 1.082 & 8.140 \\
Protein intake & $0.039^{*}$ & 2.895 & 1.057 & 7.933 \\
The inciden of illness & 0.114 & 2.178 & 0.830 & 5.713 \\
\hline
\end{tabular}

$*=\mathrm{p}<0.05$

Malnutrition not only occurs in Indonesia but also in another country such as India [7]. The prevalence of malnutrition in Bali is $13 \%$ in 2013, nutritional status in Bali is still a matter of concern [8,9] Besides malnutrition, the division of vitamins especially vitamin $\mathrm{A}$ is also a serious problem experienced in Indonesia [10]. 
Multivariate analysis showed children who did not get exclusive breastfeeding had a risk of 3.005 times more likely to suffer from poor nutrition compared to children who received exclusive breastfeeding. Results are obtained in accordance with the hypothesis stated that exclusive breastfeeding has meaningful relationship statistics on the nutritional status of children aged 7-18 months. Besides that, the multivariate analysis also obtained that there were no relationships between the incidence of illness and the status of child nutrition ( $\mathrm{p}>0.05)$.

Another study also found the same result that breastfeeding has the most significant relationship and the strongest influence $(\mathrm{p}=0,000 ; \mathrm{OR}=8.09)$ with nutritional status of children under the pattern of giving MP-ASI, intake calories and sick history [11]. Different results were found in the incidence of illness, in the study the history of infectious diseases (diarrhea and ARI) in the last 3 months had a significant relationship with the nutritional status of children $(p=0.001)$. These differences in results occur because of differences in sampling techniques and age of toddlers. This research is also in line with the research conducted by Widyastuti in 2009, who obtained an OR (odds ratio) of 0.49 , which means babies who were given exclusive breastfeeding has a risk of 0.49 times suffering malnutrition compared to infants who did not get exclusive breastfeeding which is almost 2 times greater risk of suffering from malnutrition [12].

Other studies also show that there is significant relationship between giving exclusive breastfeeding with nutritional status of children $(p=0,000)$ [13] This research is also supported by results research by Fitri et al. (2014), that normal growth is found in infants who are exclusively breastfed compared to babies who do not get it exclusive breastfeeding $(\mathrm{OR}=1.62)$ [14]. It was concluded that exclusive breastfeeding affected the growth of infants, where infants who received exclusive breastfeeding had a chance to experience normal growth 1.62 times greater than babies who were not given exclusive breastfeeding. This is because the nutrients contained in breast milk can meet the needs of babies to achieve normal growth until they are 6 months old without having to provide additional food [15].

\section{Conclusions}

There was a significant relationship between exclusive breastfeeding and nutritional status in children aged 7-18 months in Puskesmas Pupuan I ( $p=0.030)$, and children who did not get exclusive breastfeeding were 3.005 times more at risk of suffering from poor nutrition than children who received exclusive breastfeeding

\section{References}

[1] Lestari D, Zuraida R and Larasati T A 2013 Hubungan tingkat pengetahuan ibu tentang air susu ibu dan pekerjaan ibu dengan pemberian ASI eksklusif di kelurahan Fajar Bulan. Medical Journal of Lampung University 2(4) p 88-99

[2] Nilakesuma A, Jurnalis Y D and Rusjdi S R 2015 Hubungan status gizi bayi dengan pemberian ASI ekslusif, tingkat pendidikan ibu dan status ekonomi keluarga di Wilayah Kerja Puskesmas Padang Pasir Jurnal Kesehatan Andalas 4(1) p 37-44

[3] Almatsier, Sunita. 2009 Prinsif dasar ilmu gizi. Jakarta. Gramedia

[4] Badan Kependudukan dan Keluarga Berencana Nasional (BKKBN) 2013 Penelitian dan pengembangan kesehatan Departemen Kesehatan RI. Badan Litbangkes RI 2012. Viewed 25 oktober 2013, from: http://www.dinkes.jabarprov.go.id/

[5] Susanti N. 2011. Peran ibu menyusui yang bekerja dalam pemberian ASI eksklusif bagi bayinya. EGALITA 6(2) p 165-176. 
[6] Surioka I P, Kusumajaya A A, Larasati N 2011 Pengaruh energi, protein, vitamin dan frekuensi sakit karena infeksi terhadap status gizi pada balita Jurnal Ilmu Gizi Indonesia 1(2) p 97-104

[7] Vipin C K P 2009 Malnourished Indian children: The Post-reform scenario, ed Dr. K. Gangadharan (New Delhi-Serial Publications)

[8] WHO 2015 Nutrition status. Regional office for South-East Asia : World Health Organization

[9] Departemen Kesehatan (Depkes) RI. 2012. Pedoman umum pemberian makanan pendamping air susu ibu (MP-ASI) lokal Tahun 2006. Viewed 6 Oktober 2013 from: http://gizi.depkes.go.id/asi/Pedoman\%20 MPASI\%

[10] Cahyawati P N 2018 Transport, Metabolisme dan Peran Vitamin A dalam Imunitas Wicaksana Jurnal lingkungan dan Pembangunan 2(2) p 43-47

[11] Yogi E 2013 Pengaruh pola pemberian ASI dan pola makanan pendamping ASI terhadap status gizi bayi usia 6 -12 bulan Jurnal Delima Harapan 2(1) p 14-18.

[12] Widyastuti E 2009 Hubungan riwayat pemberian asi dengan status gizi bayi usia 6-24 bulan. Jurnal Kesehatan Andalas 11 p 120-131.

[13] Giri M K W, Muliarta I W and Wahyuni N P 2013. Hubungan pemberian ASI eksklusif dengan status gizi balita usia 6-24 bulan di Kampung Kajanan, Buleleng. Jurnal Sains dan Teknologi 2(1) p 120-125.

[14] Fitri D I, Chundrayetti E and Semiarti R 2014 Hubungan pemberian ASI dengan tumbuh kembang bayi umur 6 bulan di Puskesmas Nanggalo Jurnal Kesehatan Andalas 3(2) p 136-140

[15] Muchina E and Waithaka P 2010 Relationship between breastfeeding practices and nutritional status of children aged 0-24 months in Nairobi, Kenya African Journal of Food, Agriculture, Nutrition and Development 10(4) p 2358-2378. 